\title{
ARSITEKTUR DAN DESAIN KOTA HIBRIDA PADA KANTOR POS DAN ALUN-ALUN DI MEDAN
}

\author{
Hybrid Architecture and Urban Design of Pos Office Building and \\ Open Space in Medan
}

\section{R. Siti Rukayah ${ }^{1}$ dan Sudarmawan Juwono ${ }^{2}$}

Diterima: 24 April 2018

Disetujui: 31 Agustus 2018

\begin{abstract}
Abstrak: Pusat kota tradisional memiliki komposisi alun-alun sebagai pusat pemerintahan. Hal ini terkait dengan filosofi kota sebagai pusat negara yang dipimpin oleh raja. Kota-kota kabupaten di Jawa mengadopsi konsep ini dengan komposisi yang mirip. Di era kolonial Belanda abad 18-19, jalur postweg menghubungkan kota-kota kabupaten di Jawa, dengan posisi kantor pos berada di dekat pusat kota. Medan di Sumatera menjadi kasus untuk meneliti bagaimana konsep arsitektur kantor pos dan konsep lapangan Merdeka yang menyerupai alun-alun sebagai karya pemerintahan Belanda kala itu. Tujuan penelitian ini adalah mengungkap konsep bangunan dan kawasan kota peninggalan pemerintahan Belanda di Medan dengan studi kasus kantor pos yang berada di titik nol kota dan lapangan Merdeka sebagai pusat kota. Penempatan lapangan Merdeka dan kantor pos menjadi metode untuk membaca konsep pusat kota baru di luar pusat pemerintahan. Dengan menggunakan metode historis dan grounded research, ditemukan bahwa di Medan terdapat keunikan, yaitu ciri hibrida pada desain kota yang terpengaruh oleh konsep Jawa dan Belanda serta Jawa, Melayu, Arab dan China yang mempengaruhi konsep bangunannya.
\end{abstract}

Kata kunci: kantor pos, pusat kota lama, Medan, hibrida

\begin{abstract}
The traditional citi center in Java has a composition of the square. The philosophy of the city is as the center of the country which is lead by the king. The regency cities in Java adopt this concept with the similar composition. In the Dutch colonial era of the 18-19th century, the postweg line is connected the regency cities in Java, with the post office located near the city center. Medan in Sumatra becomes the case to eximen how the architectural concept of the post office and Merdeka field (resembling the square in Java) as the work of the Dutch government at that time. The purpose of this study is to uncover the concept of the post office located at the zero point of the city and Merdeka Field as the square in the city center. By using the historical and grounded research, it is found that Medan is a unique city. The hybrid architectural design of the post office classifies the shape of the old city center in Medan, which has the hybrid concept which has the philosophy of meeting various cultures. The Java and Dutch concept for urban design is affected by Java, Malay, and Chinese for building design.
\end{abstract}

Keywords: post office, old city center, Medan, hybrid

\footnotetext{
${ }^{1}$ Architecture Department of Engineering Faculty, Universitas Diponegoro

${ }^{2}$ PT. Pos Indonesia, Architecture Department, Universitas Bung Karno
}

Korespondensi: tututrsiti@yahoo.com; 


\section{PENDAHULUAN}

Pada zaman dahulu sebelum dikenal sebagai kota Medan, kota ini bernama Tanah Deli karena berawak dari kesultanan Deli. Setelah tahun 1860-an, penguasa-penguasa Belanda mengunjungi tanah ini dan mulai membebaskan tanah yang berawa-rawa untuk perkebunan tembakau dan mengubah Deli menjadi pusat perdagangan yang mahsyur dengan julukan het dollar land atau tanah uang. Perdagangan yang maju mendorong perkembangan kota Medan menjadi pusat pemerintahan. Istana Kesultanan Deli yang semula berada di kampung Bahari (Labuhan), dipindahkan ke Medan pada tahun 1891 (Ginting \& Rahman, 2016). Di era tahun 1875, sebelum pemindahan kesultanan Deli ke Medan, Esplanade atau lapangan Merdeka telah didesain menjadi pusat pemerintahan. Pemerintah membangun beberapa bangunan sebagai simbol untuk memfasilitasi perdagangan tembakau. Di sekitar lapangan Merdeka secara bertahap dibangun gedunggedung untuk mewadahi kebutuhan perkebunan saat itu. Fungsi bangunan yang ada di sekitar lapangan Merdeka merupakan bagian dari fasilitas penunjang perkebunan dan fasilitas pendukung bagi masyarakat kolonial baik Inggris maupun Belanda saat itu. Selain dibangunannya beberapa kantor dan gedung penunjang di sekitar lapangan Merdeka, juga dibangun bangunan-bangunan penunjang di beberapa lorong di sekitar lapangan Merdeka yang mempunyai akses ke pusat kota saat itu bahkan sampai saat ini (Utami dkk, 2004).

Konsep lapangan Merdeka hampir mirip dengan alun-alun di Jawa, yaitu sebuah ruang terbuka yang berada di depan sebuah bangunan utama kota, yaitu gedung Balai Kota. Kawasan ini lebih mencerminkan fungsi sebagai pusat pemerintahan Belanda dibandingkan dengan pusat kultural yaitu kawasan Kesultanan Deli yang berada di luar area pusat kota ini, yang menjadi pusat kegiatan kultural dengan Istana Maimoon sebagai landmark-nya (Ginting \& Rahman, 2016). Keberadaan lapangan Merdeka ini menandai koordinat titik nol yang hampir mirip juga dengan kota-kota kabupaten di Jawa yang berada di jalur postweg. Mirip juga dengan tata kota di Jawa, yang letak gedung kantor pos di Jawa berada di pusat kota dan di jalur postweg yang dibangun oleh Daendels pada tahun 1809-1811 (Pratiwo.P.Nas, 2002), keberadaan kantor pos Medan merupakan tempat yang sangat strategis, yaitu berada di dekat lapangan kota dan titik nol kota. Posisi ini untuk memudahkan transportasi surat dan barang. Letak gedung kantor pos juga berdekatan dengan stasiun kereta api.

Pembangunan kota Medan dilakukan dua tahap, yaitu pembangunan pusat pemerintahan dan pusat kesultanan. Sebagai pusat kesultanan, tata kota dipisahkan dengan pusat pemerintahan Belanda. Tata kota pusat pemerintahan Belanda mirip dengan pusat kota tradisional di Jawa yang memiliki komposisi lapangan dan kantor pemerintahan. Di Jawa, pusat kota dikelilingi oleh Masjid dan Keraton atau pusat pemerintahan terkait dengan filosofi kota sebagai pusat negara dan pusat kegiatan religious. Sementara itu, di lapangan Merdeka tercermin kebudayaan yang menyimbolkan pusat pemerintahan dengan bangunan di seklilingnya sebagai fasilitas kegiatan perkebunan. (Ginting \& Rahman, 2016)

Di Medan, posisi kantor pos berada di sisi Utara Lapangan Merdeka yang sering dimanfaatkan masyarakat sebagai sarana olahraga, tempat interaksi, aktivitas sosial dan kebutuhan rekreasi (Mandai, 2016). Yang menarik adalah meskipun mirip dengan ruang terbuka di Jawa, keberadaan kantor pos tidak berada tepat di alun-alun. Kantor pos Medan berada tapat di Utara lapangan Merdeka berdekatan dengan stasiun dan kantor pusat pemerintahan Belanda.

Paulus, 1917, mengutip tentang komposisi alun-alun dari buku Encyclopedie van Nederlandsch Indie

......... Di hampir setiap tempat kediaman Bupati, seorang kepala distrik di Jawa, orang selalu menjumpai adanya sebuah lapangan rumput yang luas, yang dikelilingi oleh pohon beringin di tengahnya. Lapangan inilah yang dinamakan 'alun-alun'. Di kota-kota 
bekas kerajaan kuno (seperti Surakarta dan Yogyakarta), mempunyai dua buah 'alun-alun', sebuah terletak di Utara Kraton dan sebuah lagi terletak disebelah Selatan Kraton. Di permukaan alun-alun tersebut tidak boleh ada rumput tumbuh dan diatasnya ditutup dengan pasir halus. Di bagian Selatan dari alun-alun tersebut terdapat pintu masuk yang menuju ketempat kediaman Raja atau Bupati, dimana disana berdiri sebuah pendopo Masjid. Karena fungsi mengarah pada kiblat diletakkan pada sebelah Barat dari alun-alun.

Pusat pemerintahan lokal berada di Istana Maimun sebagai Istana Kesultanan Deli. Pembangunan istana ini dimulai pada 26 Agustus 1888 dan selesai pembangunannya pada 18 Mei 1891. Arsitektur istana ini merupakan perpaduan antara ciri arsitektur Moghul, Timur Tengah, Spanyol, India, Belanda dan Melayu. Pembangunan istana menandai puncaknya jaman kekayaan ekonomi perkebunan.

Medan sebagai embrio sebuah kota, secara kronologis berawal pusat pemerintahan lokal dan pusat pemerintahan Belanda. Kala itu, Medan masih terdiri dari dua kecamatan, yaitu Kecamatan Medan Maimun, dan Medan Polonia. Kawasan Medan Maimun adalah kawasan Istana atau Kerajaan Deli yang dikuasai oleh Pemerintah Kerajaan Deli sedangkan kawasan Medan Polonia adalah kawasan yang dikuasai oleh Pemerintah Kolonial Belanda (Siregar, 2015). Dengan demikian, Medan memiliki struktur kota dengan tipe multiple nuclei atau struktur kota dengan pusat kegiatan yang tidak berpusat pada satu kawasan saja (Pasaribu, n.d.).

Sampai saat ini, masih banyak bangunan - bangunan tua di sekitar Balai Kota Medan yang masih kokoh berdiri menghiasi kota Medan. Kesawan Square, Gedung Bank Mandiri, Bank Indonesia, Kantor Pos dan sebagainya menjadi bukti nyata bahwa Medan memiliki peradaban peninggalan pemerintahan Belanda dahulunya. Di Jawa, peninggalan arsitektur bergaya kolonial didominasi oleh arsitek Thomas Karsten (Coté, 2014). Pertanyaan yang muncul adalah bagaimana konsep arsitektur kantor pos dan konsep lapangan Merdeka sebagai karya pemerintahan Belanda kala itu? Tujuan Penelitian ini adalah mengungkap konsep bangunan dan kawasan kota peninggalan pemerintahan Belanda di Medan dengan studi kasus kantor pos yang berada di titik nol kota dan lapangan Merdeka sebagai pusat kota.

\section{METODE}

Riset ini merupakan serial penelitian tentang kantor pos di Jawa sebagai bangunan heritage yang telah dilakukan sejak tahun 2015. Sejak tahun itu, peneliti telah mengumpulkan data-data kuno tentang bangunan kantor pos. Untuk mengungkap konsep perancangan karya kolonial Belanda, peneliti memerlukan data-data kuno yang diperoleh dari tropen museum dan kitlv.nl. Penelitian ini menggunakan metode historis dan grounded research dengan melihat objek penelitian sebagai daerah amatan dan melihat bangunan sebagai fokus amatan. Dalam hal ini, bangunan kantor pos dan lapangan Merdeka Medan menjadi objek penelitian yang akan dieksplorasi secara keseluruhan untuk mendapatkan hasil data berupa identifikasi elemen bangunan dalam urban design. Penelitian ini merupakan penelitian deskriptif dan studi kasus sejarah dengan melihat bangunan sebagai gambaran yang difokuskan pada fasad bangunan dan elemen bangunan. Ada beberapa elemen yang akan dianalisa berdasarkan bentuk bangunannya namun hanya sebagai penjelasan analisa saja (dalam hal ini terkait peranan dominan dengan menggunakan konsep bentuk bangunan).

Dengan menggunakan gambar-gambar kuno dan peta kuno, maka metode pembacaan peta dan gambar menjadi lebih dominan dari sumber narasi (Pole, 2004). Pendekatan ini menggunakan gambar lama sebagai sumber informasi. Selain itu ekplorasi mendalam lain dilakukan dengan melakukan pada latar belakang sejarah guna menemukan relevansi konten tema penelitian dengan konteks lingkungan dan budaya. 


\section{TEMUAN DAN KAJIAN}

\section{Pusat Kota di Jawa sebagai Referensi Tidak Tertulis Desain Pusat Kota di Indonesia}

Alun-alun dan struktur kota di Jawa pada zaman prakolonial dapat dikenali dengan adanya ciri-ciri yaitu: poros Utara-Selatan, letak Mesjid, fungsi dan letak Alun-Alun, Keraton dan Pasar, yang pada hakekatnya berasal dari zaman pra Islam (Handinoto, 1992). Penataan kota-kota Jawa pada zaman prakolonial didasarkan atas konsep mikrokomis hirarkis dan mikrokosmis dualistis. (S. Hartono, 2005). Poros sumbu Utara-Selatan merupakan penerapan konsep cosmology, yaitu ruang dianggap sebagai tiruan tempat untuk seluruh lingkungan kosmik (Geldern, 1982) (S. Hartono, 1972)(Mulyadi, 2010).

Dalam konsep kosmis, orientasi ruang menentukan pola keterkaitan antara seluruh kekuatan kosmos. Setiap jalan di kota didesain dengan memberikan kehormatan pada kosmik; sehingga harmoni dan keseimbangan antara seluruh kekuatan kosmik bisa terjadi. Bentuk kota-kota tradisional di Jawa dan di pulau Bali cenderung mengikuti pada tatanan sumbu Timur-Barat atau sumbu Utara-Selatan (Mulyadi, 2010) (S. Hartono, 1972). Orientasi bangunan dikembangkan sesuai dengan orientasi seperti itu juga. Sementara itu, tatanan kota merupakan replika kosmis dengan pusat kota berada pada persimpangan antara dua sumbu kekuatan kosmis. Posisi tersebut diyakini sebagai titik kritis yang bisa memberi kekuatan spiritual. Di persimpangan sumbu terletak alun-alun dan pusat kota tradisional Jawa (Karsono, 2008)

Sumbu Utara-Selatan dan sumbu Timur-Barat menjadi pola dasar yang memiliki 2 (dua) fenomena:

1. Di era kota kesultanan: Sebagai sumbu imajiner berdasarkan agama dan kosmologi, dan juga basis atas hal-hal suci yang mereka yakini.

2. Di era pemerintahan kolonial Belanda: Sebagai nilai estetika melalui orientasi terhadap sesuatu, perkembangan sumbu orientasi sejajar dengan realitas alam.

Pola grid alam muncul dari sawah dan pola kebun yang memiliki orientasi UtaraSelatan. Pengaruh Islam memberi kontribusi positif dalam pembentukan ruang dalam kota dengan adanya masjid yang berdampingan dengan kerajaan (Rukayah, Siti, R and Hartuti, 2013). Sumbu pada pengaruh Belanda dibawa dari Barat. Konsep mereka berdasarkan pada upaya untuk mendapatkan estetika visual dan fisik untuk membentuk ruang linier yang pasti.

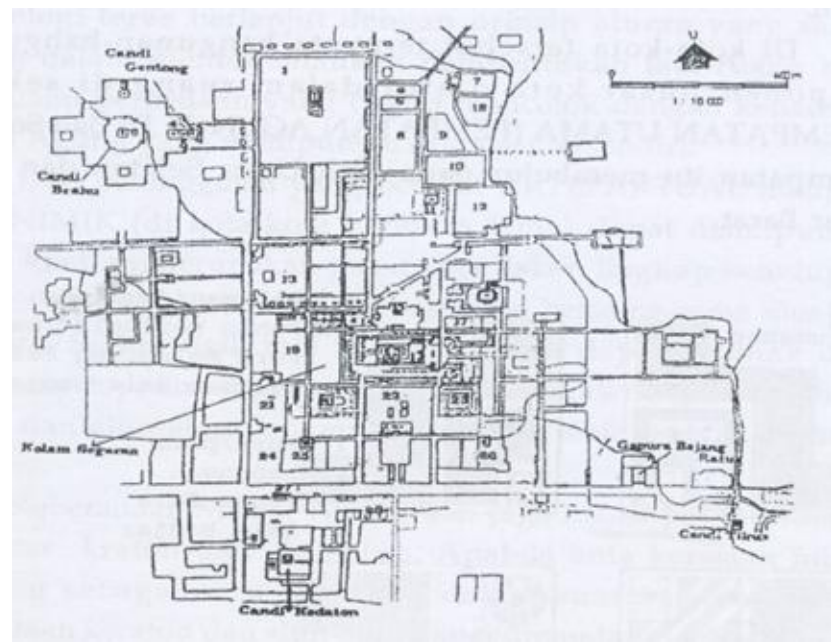

Sumber: Bapeda,1999 


\section{Gambar 1. Komposisi Pusat kota Keraton Majapahit (1293 -1500 AD) yang digambar ulang oleh Mc Lain Pont. Model ini menjadi refrensi tidak terulis bagi kota-kota kesultanan setelahnya di Jawa.}

Di era kolonial Belanda, konsep ini diadopsi pada kota-kota di Jawa dengan menempatkan alun-alun dan pusat pemerintahan di sisi Selatan (Siti, Dhanang, \& and Endang, 2016). Pada perencanan kota-kota di Jawa, di sepanjang jalur postweg yang dibangun oleh Daendels pada tahun 1809-1811, pemerintah Belanda memposisikan pusat kota dilalui oleh jalur ini. (Pratiwo, 2004).

Pada tulisan ini menjadi menarik karena menemukan perancangan pusat kota di luar Jawa yaitu di Medan. Di kota Medan, terdapat dua pusat kota yaitu pusat kota budaya dan pusat modernisasi. Pusat kota di Jawa menjadi rujukan tidak tertulis ketika pemerintah mendesain pusat kota/ esplanade di Medan. Kedua kawasan ini masuk ke dalam kawasan Historic district (Yahaya, 2017).

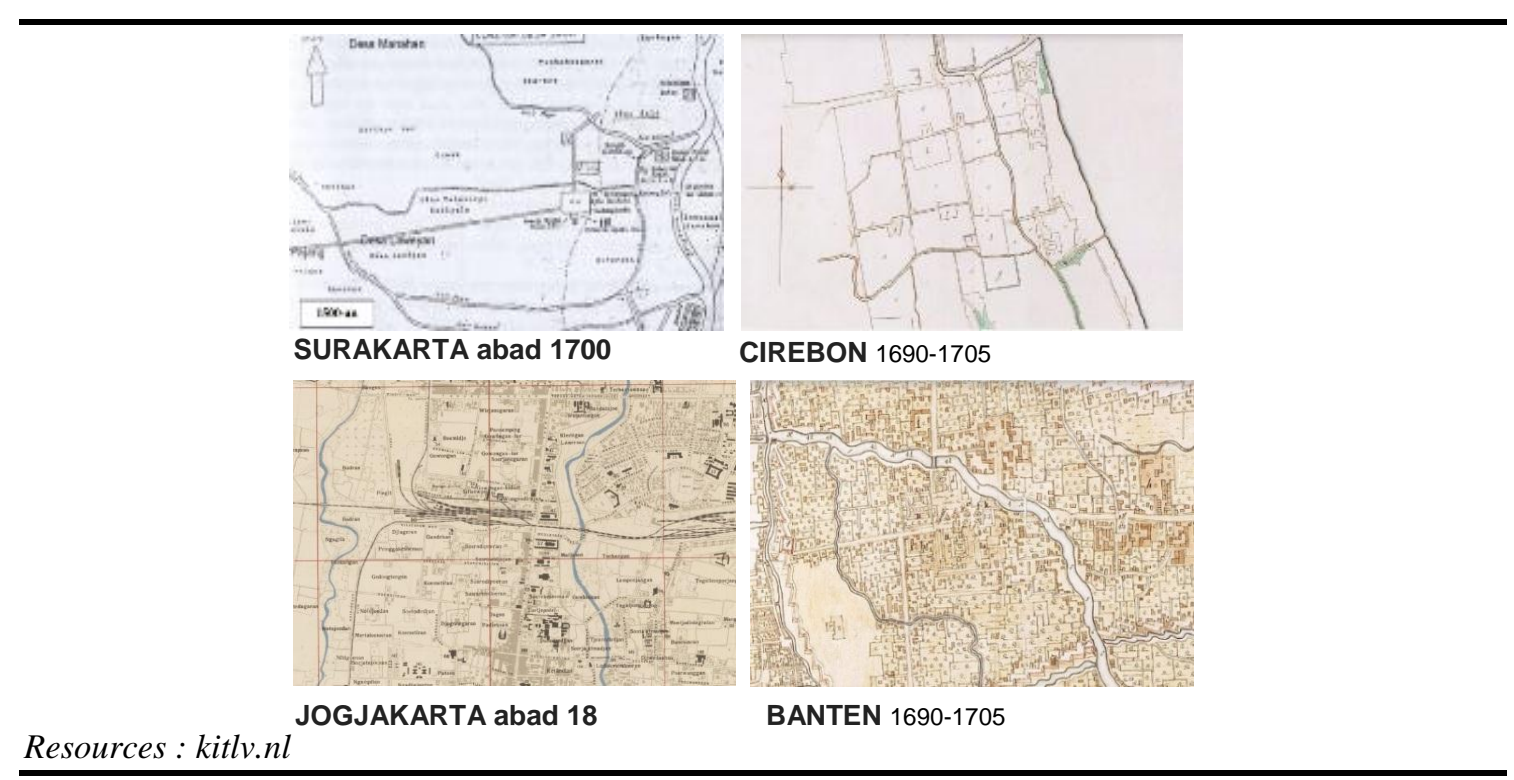

Gambar 2. Komposisi pusat kota di Surakarta, Cirebon, Jogjakarta, Banten. Lapangan/ alun-alun dikelilingi oleh Masjid dan Keraton

\section{Dualisme Pusat Kota Medan: Pusat Kultural di Deli dan Pusat Modernisasi di Esplanade}

\section{Pusat Kultural di Kesultanan Deli}

Sejak lama, kota Medan merupakan salah satu kota yang terkemuka di Sumatera bahkan di Asia Tenggara. Medan merupakan kota di pesisir timur pulau Sumatera yang menghadap Selat Malaka. Selat ini merupakan jalur strategis pelayaran internasional antara Eropa, Timur Tengah dan Timur Jauh atau Asia Tenggara sejak masa lalu. Jauh sebelum kota Medan berdiri, dari berbagai catatan para pelancong Cina maupun India, menunjukkan bahwa banyak orang berbagai suku bangsa telah mengunjungi pelabuhanpelabuhan di Sumatera yang bagian dari mata rantai Jalur Sutera (The Silk Road) melalui jalur lautan.

Sejarah kota ini konon dirintis ketika Guru Patimpus Sembiring yang berasal dari Karo Toba membangun suatu permukiman atau kampung di sini. Guru Patimpus ini antara 1614-1630 mendirikan kota Medan. Para raja disebut Sultan yang memerintah beberapa negeri di sekitar Medan merupakan keturunan Melayu dan masyarakat Batak. Kisah ini 
menunjukkan alkulturasi budaya lokal Batak, Melayu, dan budaya Islam membentuk kebudayaan Medan seperti yang dapat kita lihat sekarang ini (Julaihi Wahid, Bambang Karsono, 2009).

Budaya Melayu merupakan budaya dominan di antara berbagai budaya di Medan. Kebudayaan Melayu identik dengan tradisi Islam di Sumatera maupun Semenanjung Malaya. Kebudayaan ini dipengaruhi tradisi dan budaya suku bangsa yang membawanya seperti budaya Arab dan India. Maka bisa dimengerti dominasi budaya-budaya tersebut dalam seni dan budaya masyarakat Melayu (Ali, 2014).

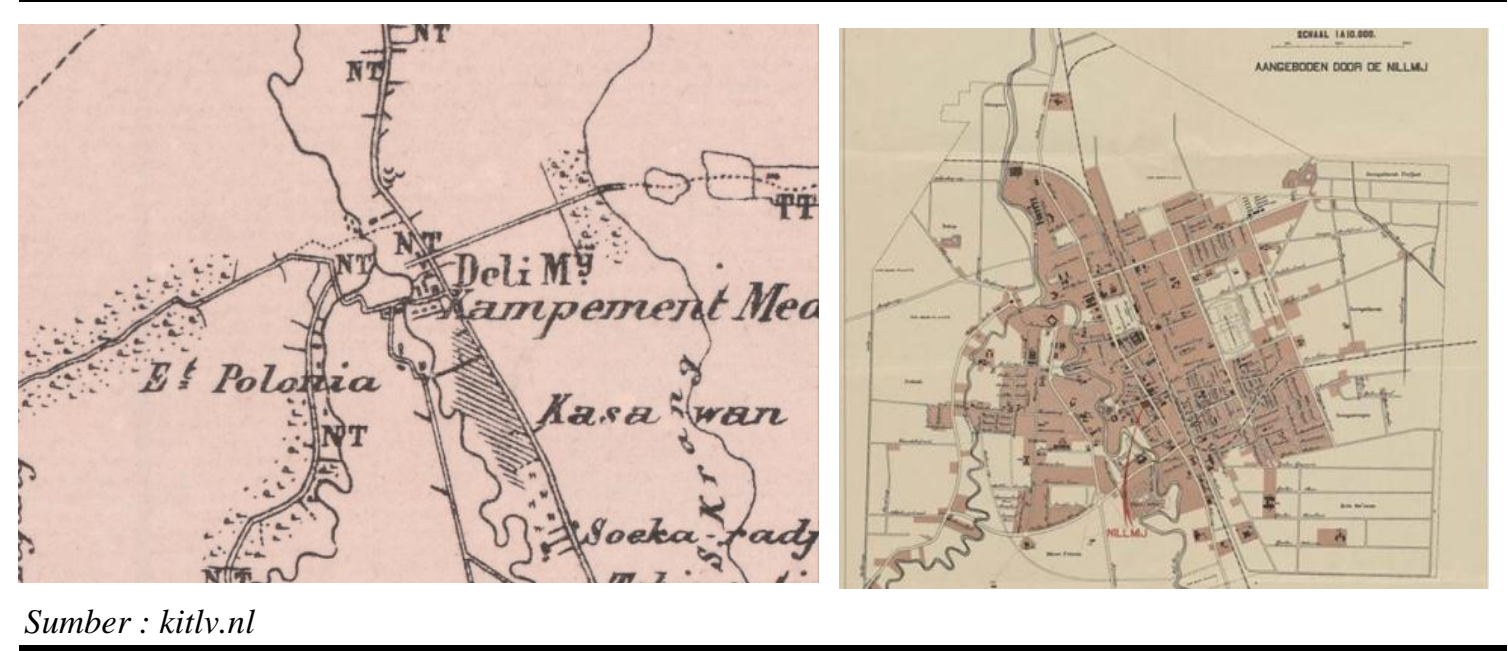

Gambar 3. Perkembangan Kota Medan Tahun 1876 (Kanan) dan Tahun 1915 (Kiri), Dari Pemilahan Kesultanan Deli Dan Pusat Pemerintahan Belanda Hingga Lapangan Merdeka Menjadi Pusat Kota yang Bercirikan Modern
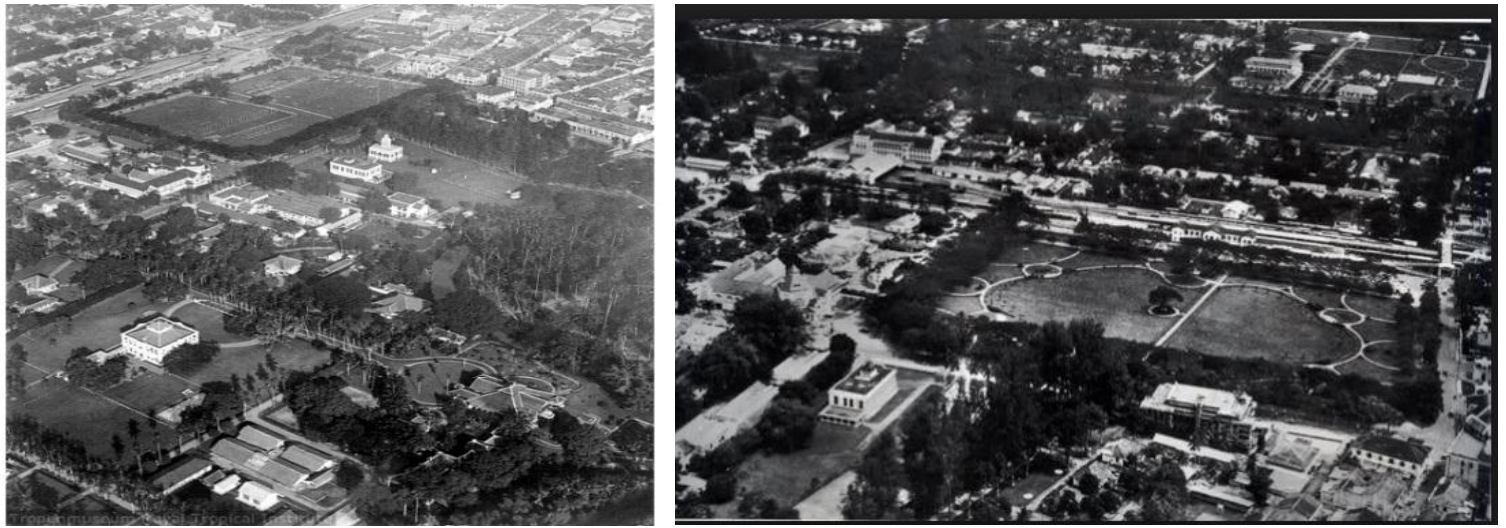

Sumber: kitlv.nl

Gambar 4. Foto Udara Kesultanan Deli dan Pusat Pemerintahan Belanda Kawasan Istana Maimoon Dan Masjid Sebagai Pusat Budaya (Kiri) dan Lapangan Merdeka, Pusat Pemerintahan Belanda Dan Kegiatan Failitas Perkebunan (Kanan)

Islam menjadi agama resmi kerajaan-kerajaan Melayu dan pola pemerintahan mengikuti model pemerintahan Islam yang ada sebelumnya seperti di Aceh serta Pasai. 
Tidak mengherankan bahwa banyak para pendatang yang mendatangi serta menetap di kota ini sehingga membentuk keragaman bangsa dan budaya. Pengaruh kebudayaan Islam ini dapat dilihat dari berbagai unsur kesenian, bangunan, sastra, dan adat istiadat masyarakat setempat. Pada budaya arsitektur dapat dilihat adanya bangunan masjid dan surau sebagai bagian tata bangunan dalam perkampungan atau negeri. Bahkan kita juga melihat ada jejak arsitektur Melayu pada bangunan kantor pos Medan. Nama kota Medanpun berasal dari bahasa Arab yaitu "Maidan "artinya tempat berkumpul atau lapangan. Kata Maidan ini diserap ke dalam bahasa Melayu kemudian menjadi kata Medan.

\section{Pusat Modernisasi di Esplanade Lapangan Merdeka sebagai Hybrid Urban Design}

Lay out kota Medan bisa dikatakan di awali pada tahun 1870 (Julaihi Wahid, Bambang Karsono, 2009). Pembangunan Kesultanan Deli di sisi Selatan dan sentral square di esplanade sekarang lapangan Merdeka, menjadi dua kelompok tata perkotaan dengan konsep pemilahan pusat budaya dan pemerintahan lokal Kesultanan Deli serta central square sebagai pusat pemerintahan dan bisnis (lihat gambar 5)

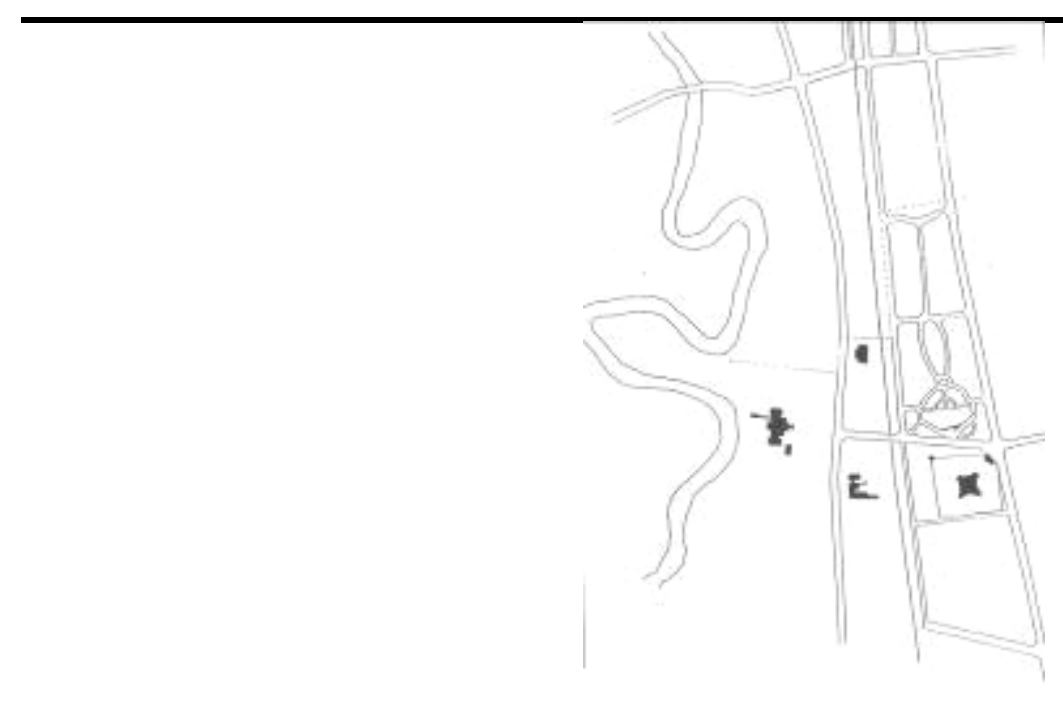

Sumber: Julaihi Wahid, Bambang Karsono, 2009

\section{Gambar 5. Peta Perkembangan Periode Tahun 1888-1920. Kesultanan Deli dan lokasi esplanade/ lapangan Merdeka.}

Struktur ruang kota sejak awal direncanakan berkonsep modern (Julaihi Wahid, Bambang Karsono, 2009). Bangunan di sekeliling lapangan yang mencirikan mirip alunalun adalah keberadaan Balai Kota. Namun, Balai Kota berada di sisi Barat, bukan di sisi Selatan seperti konsep alun-alun di Jawa. Komposisi bangunan terdiri dari stasiun kereta api (1885) di sebelah timur Esplanade, 'wiitte club' (1887), Hotel De Boer (Dharma Deli) 1898, Balaikota (townhall) 1909, dan Javasche Bank (Bank Indonesia) 1909. Grand Hotel Medan, 1887, Kantor pusat baru Deli Company (1919), dan Kantor Pos (1911) berada di sisi selatan Esplanade (Julaihi Wahid, Bambang Karsono, 2009). Di sebelah barat Esplanade, terletak gedung Javasche Bank (1910). Gedung kantor British plantation company Harrissons \& Crosfield (Lonsum) yang diberi nama Juliana Building terletak di sudut jalan Kesawan dan Esplanade, dan gedung ini adalah yang pertama menggunakan lift di kota Medan. 
Dapat disimpulkan bahwa sebagai pusat kota kreasi pemerintahan Belanda, lapangan Merdeka memiliki konsep peranakan Jawa dan Belanda. Letak lapangan merdeka di depan gedung Balai Kota sangat mirip dengan konsep alun-alun dan pusat pemerintahan di Jawa. Sementara itu, lokasi gedung-gedung fasilitas perkebunan di sekeliling lapangan mencerminkan konsep plaza/ square di Belanda. Lapangan Merdeka sebagai wajah kota Medan mencerminkan kekuatan pemerintahan dan kesusksesan perkebunan.

Struktur awal kota Medan memiliki konsep dualisme kultural (Kesultanan Deli) dan Modern (Espalanade). Pengaruh tata ruang berdasarkan kesultanan Islam sedikit memberi warna pada layout Kesultanan Deli. Kesultanan Deli menjadi simbol tunggal bagi raja-raja di Tapanuli karena di Tapanuli tidak ada sultan, yang ada adalah radja kampung yang secara adat disebut 'radja huta'. Hal ini terlihat dengan pembangunan istana yang megah bagi Sultan Deli.

Layout awal pengembangan kota Medan tampaknya mengikuti pola alur sungai yang berada di sisi Barat. Dengan demikian, sumbu Utara-Selatan terbentuk dan menjadi pola dasar yang bukan merupakan sumbu imajiner apalagi sumbu sakral berdasarkan agama dan kosmologi seperti yang dikenal pada tata kota di Jawa. Sangat dimungkinkan sumbu Utara-Selatan terbentuk sebagai penghubung antara Kesultanan Deli di sisi Selatan dan Esplanade di sisi Utara sebagai nilai estetika yang diperoleh melalui linkage visual dan linkage struktural sebagai panduan arah orientasi.

\section{Kantor Pos Medan : Hibrida Arsitektur}

Dalam bukunya bernama "Mission to the Eastcoast of Sumatera" yang diterbitkan tahun 1826, seorang Inggris yang bernama John Anderson menceritakan kunjungannya ke Medan pada tahun 1823. Medan saat itu masih merupakan suatu kampung kecil dengan penduduk sekitar 200 orang. Corr Passchier menceritakan bahwa pada tahun 1860-an, pelabuhan lama Labuan Deli telah mulai ramai dengan perdagangan mancanegara. Sebuah kantor pos dibangun untuk melayani kebutuhan masyarakat. Perkembangan Medan menjadi kota besar dengan menerima banyak berbagai budaya lokal maupun asing seperti India, Cina dan Belanda. Hal ini semakin pesat terjadi ketika Belanda menguasai Medan dan sekitarnya. Proses interaksi budaya dengan para pendatang semakin tinggi. Orang India, Arab maupun orang-orang asing dari daratan Cina didatangkan sebagai pekerja dan menempati Medan. Jejak-jejak alkulturasi budaya dalam konteks arsitektur ini dapat dilihat dari berbagai bangunan yang ada di sini. Pemerintah Belanda membangun kota ini baik secara fisik maupun sosial sebagai kota yang memiliki ciri-ciri kota kolonial.

Dalam perkembangan arsitektur dari segi masa, perubahan bentuk dapat dibedakan dalam dua hal, yaitu yang pertama perubahan secara perlahan atau disebut evolusioner dan yang kedua secara cepat, yang digolongkan ke dalam kategori pertama adalah arsitektur klasik bahkan beratus-ratus tahun. Arsitektur modern berkembang dan berubah dengan cepat, sejalan dengan cepatnya perkembangan teknologi dan penduduk. Arsitektur kolonial termasuk dalam kategori kedua yaitu arsitektur modern. Arsitektur kolonial di Indonesia adalah fenomena budaya yang unik, tidak terdapat di lain tempat, juga pada negara-negara bekas koloni. Dikatakan demikian karena terjadi percampuran budaya antara penjajah dengan budaya Indonesia yang beraneka ragam (Sumalyo, 1993).

Budaya kolonial Belanda yang dominan tidak serta merta menghapuskan lokalitas tersebut bahkan sebaliknya beradaptasi dengan budaya setempat. Cara-cara seperti ini merupakan kebiasaan orang Belanda untuk melakukan adopsi unsur-unsur lokal. Ciri arsitektur karya pemerintah Belanda yang mengadopsi konsep lokal yang beriklim tropis merupakan konsep yang berkelanjutan. Prinsip bangunan berkelanjutan ini penting diimplementasikan mengingat banyak masalah yang menyangkut bangunan dan lingkungan yang memerlukan penanganan serius dari pemerintah dan masyarakat. Di 
antara masalah tersebut adalah kekurangan pasokan energi, dan inefisiensi penggunaan energi dalam bangunan (Hidayat, 2017). Keberlanjutan arsitektur tersebut membentuk karakter kota Medan yang pluralistik dan unik. Sama seperti yang telah dijelaskan di atas tentang perancangan kotanya, karya arsitektur yang berkelanjutan mampu memadukan konsep lokal dan konsep kolonial. Pada desain pusat kotanya, keberlanjutan terbentuk pada perpaduan konsep lokal alun-alun dan konsep square di negeri Belanda. Salah satu peninggalan kolonial di kawasan pusat kota Medan adalah gedung Kantor Pos Medan. Gedung ini hingga sekarang masih berfungsi sebagai wadah pelayanan pos.

Bangunan kantor pos Medan menampakkan berbagai pengaruh budaya yang menjadi ciri khas kota Medan. Menurut Luckmann dan Passchier pelayanan pos di Medan sudah ada sejak tahun 1879 atau 1883. Sebelumnya, pada tahun 1860-an, sebuah kantor pelayanan pos juga telah didirikan di pelabuhan lama Labuan Deli yang menunjukkan bahwa tempat ini penting bagi perdagangan masa itu.

Gedung kantor pos Medan merupakan karya insinyur Snufy dari Belanda yang juga merupakan seorang insinyur pada Dinas BOW yang bertanggung jawab penuh pada bangunan-bangunan pemerintah saat itu. Gedung kantor pos mulai dibangun pada tahun 1909 dan diselesaikan pembangunannya tahun 1911. Keterangan tahun selesai pembangunan tersebut tertera pada dinding bangunan.

Penggunaan tower di atas bangunan, banyak dilakukan oleh arsitek Belanda di Indonesia mulai tahun 1900-an sampai tahun 1940-an (Hadinoto 1996). Tower yang dipakai di Kantor Pos berbentuk segi enam. Ada beberapa bukaan kecil pada tower tersebut yang berfungsi sebagai ornamen dan juga penyesuaian terhadap iklim tropis.

Atap pada bangunan kantor pos berbentuk segi enam. Atap segi enam ini dipadu dengan tower dan dilengkapi dengan dormer pada atap tower dan atap dengan jenis gevel yang menghadap ke sisi lain. Kedua jenis atap ini mengadopsi bentukan dari kolonial Belanda yang diakulturasi dengan elemen lokal.

Bukaan di Kantor Pos juga ada dua jenis. Yang pertama, yaitu berbentuk persegi panjang dengan memanjang ke atas. Hal ini dimaksudkan agar udara dan sinar yang masuk ke dalam bangunan tidak terlalu besar. Sementara, bentuk kedua yaitu bukaan yang diberi bentukan lengkungan di bagian atas. Di tiap-tiap bukaan selalu dilengkapi dengan kisi-kisi dimaksudkan agar tidak terlalu banyak cahaya yang masuk ke dalam.

Detil-detil banyak menggunakan elemen kolonial namun tetap tidak meninggalkan elemen-elemen tradisional Sumatera khususnya Melayu atau Batak.

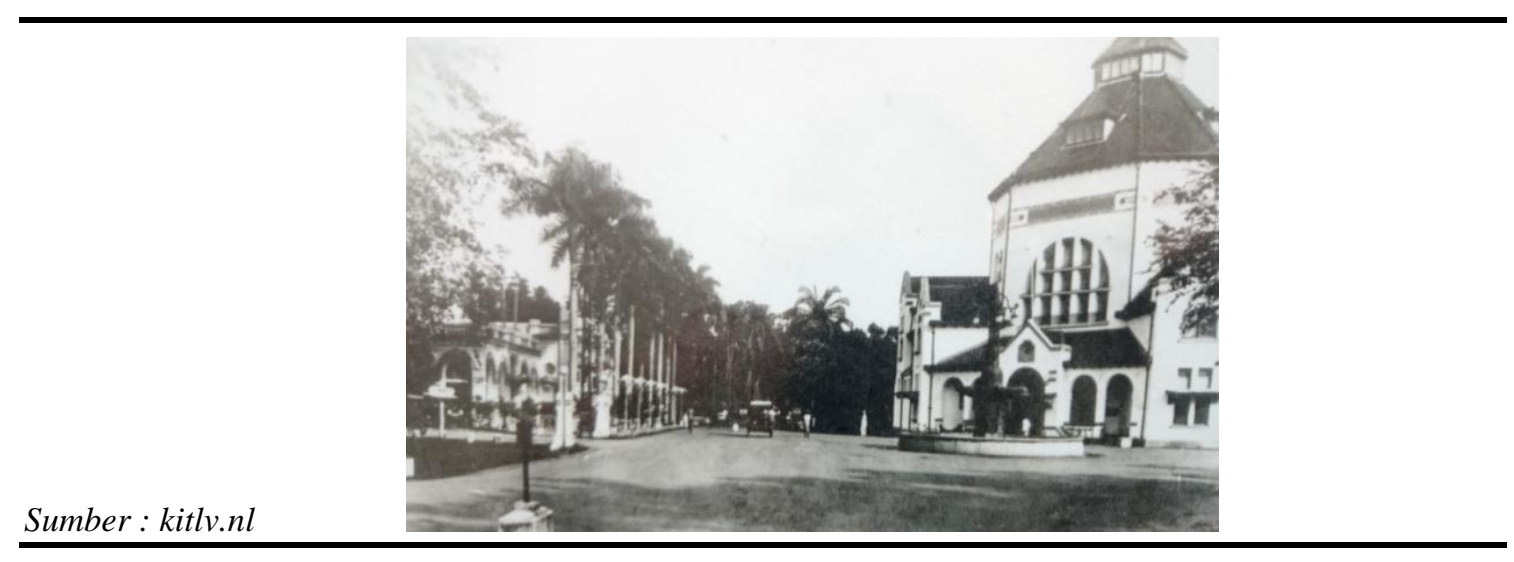

Gambar 6. Foto Lama Kantor Pos dan Lingkungannya Yang Masih Nampak Asri 
Kekhasan bangunan-bangunan kolonial awal abad 20 adalah mulai diperhatikannya unsur-unsur lokal, di samping mulai dikenal adanya teknologi bangunan yang lebih baik. Tercatat antara lain Thomas Kartsen yang memiliki kekhasan merancang dengan mengambil berbagai unsur lokal. Mc Line Point mengambil berbagai unsur rupa bangunan tradisional untuk merancang gereja Poh Sarang. Namun agak berbeda dengan bangunanbangunan kantor pos lain di Indonesia yang sebenarnya tidak banyak mengambil unsur tradisional. Sekalipun demikian banyak di antaranya tampil dengan ciri khas yang berbeda satu dengan yang lain. Benang merah antara gedung kantor pos dengan lainnya nyaris tidak ada. Misal kantor pos Yogyakarta, Semarang atau Bandung tidak ada unsur rupa atau bentuk yang menyerupai (Sudarmawan, Rukayah, 2018).

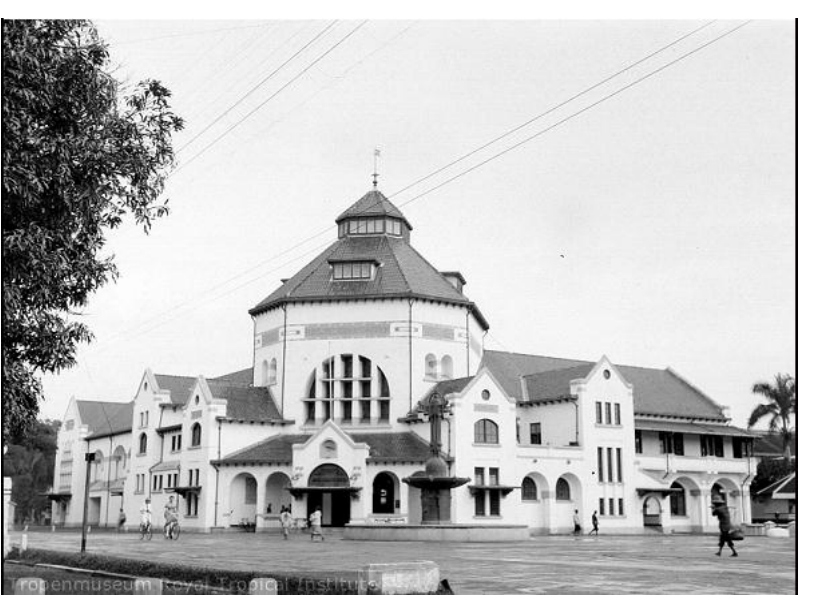

Sumber: kitlv.nl

\section{Gambar 7. Kantor Pos dari arah lapangan Merdeka.}

Jenis bangunan dengan panggung seperti ini dapat kita lihat di kantor pos Yogyakarta. Ada keinginan dari sang perancang memasukkan unsur-unsur lokal. Dalam hal ini ciri khas bangunan Melayu.

Gaya Belanda sangat terlihat jelas pada unsur atap dan dindingnya. Adanya unsur atap yang menjulang tinggi seperti menara hanya untuk menonjolkan kesan monumentalnya. Fungsinya tidak jelas namun sebagai unsur bangunan, membuat bangunan kantor pos nampak megah dan tidak kalah dengan bangunan sekitarnya. Menara ini hanya untuk membentuk rongga di dalam yang besar dan tinggi. Diameter rongga kurang lebih mencapai 20 meter. Adanya rongga ini membuat kita yang berada di dalamnya merasa pada ruang yang megah.

Tidak ada yang menyangkal bahwa bangunan kantor pos merupakan arsitektur hibrida. Hibrida atau pencampuran secara fungsional maupun simbolik adalah ekspresi perancangan arsitektur yang tanggap terhadap kondisi lingkungan namun juga upaya mempertahankan berbagai unsur sosial budaya yang masih dominan. Pada awal abad 20, konsep ini menjadi spirit para perancang untuk tidak menerapkan konsep-konsep kolonial secara membabi buta di Hindia Belanda. Selain itu, ada faktor lain yaitu politik etis yang membawa suasana baru bagi orang-orang Belanda terutama dari kalangan intelektual dalam memandang hubungan dengan bumi putera (H. Hartono., 2007). Konsep arsitektur hibrida ini lahir dari kebutuhan yang harus diakomodasi guna memenuhi faktor-faktor lingkungan maupun keinginan perancangnya.

Unsur lokal khas Melayu yang diadopsi pada bangunan kantor pos adalah pada bagian kanan menunjukkan suatu bentuk yang menyerupai rumah panggung. Jenis 
panggung ini juga digunakan pada arsitektur Istana Maimoon. Arsitektur Melayu merupakan adaptasi bentuk pada lingkungan tropis serta lingkungan yang berawa. Pada kasus gedung Kantor Pos Medan ini, tidak ada bagian kolom bawah bangunan namun adanya bagian bangunan lantai dua dengan selasar menunjukkan ada kesan sebagai rumah panggung. Konsep ini tidak ditemukan pada bangunan yang benar-benar murni kolonial seperti Javasche Bank atau gedung Balai Kota.

Sumber: kitlv.nl

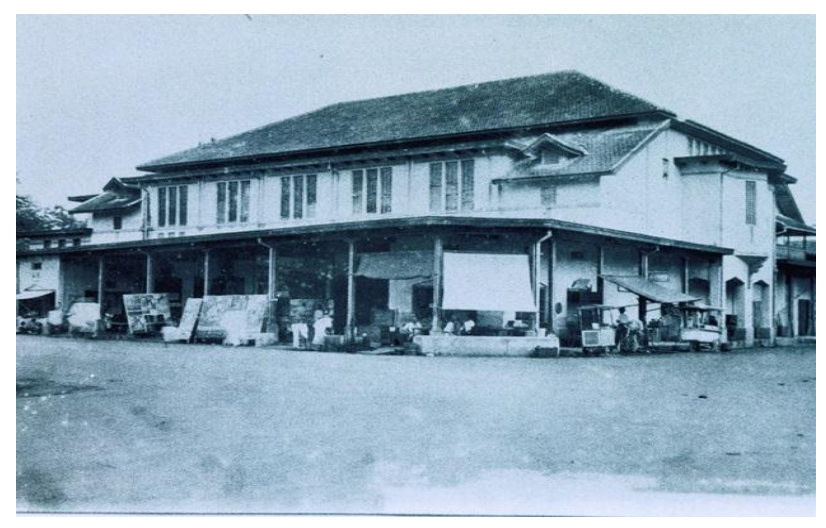

\section{Gambar 8. Konsep Rumah Panggung 2 (Dua) Bangunan Bersejarah Ini Menggunakan Konsep Panggung Sepintas Ada Kemiripan dengan Bangunan Kantor Pos.}

Kolom-kolom pemikul selasar panggung bagian kanan ditampilkan dengan baik. Kesan kokoh diperkuat dengan penonjolan pilar-pilar serta overstek kembar yang menopang bagian atas. Bahkan konstruksi baja yang menjadi penguat juga dibiarkan menonjol.

Adanya pilar-pilar ganda diteruskan pada pilar bagian selasar atas yang terbuat dari kayu. Biasanya pada bangunan kolonial yang memiliki lantai dua dengan model selasar seperti ini, tiang-tiangnya tidak sebesar ini. Agaknya sang perancang ingin menonjolkan kegagahan bangunan ini. Bangunan sayap kanan memiliki keliling selasar terbuka (sekarang ada yang ditutup) sehingga membuat bangunan ini mendapat pencahayaan dan udara yang baik.

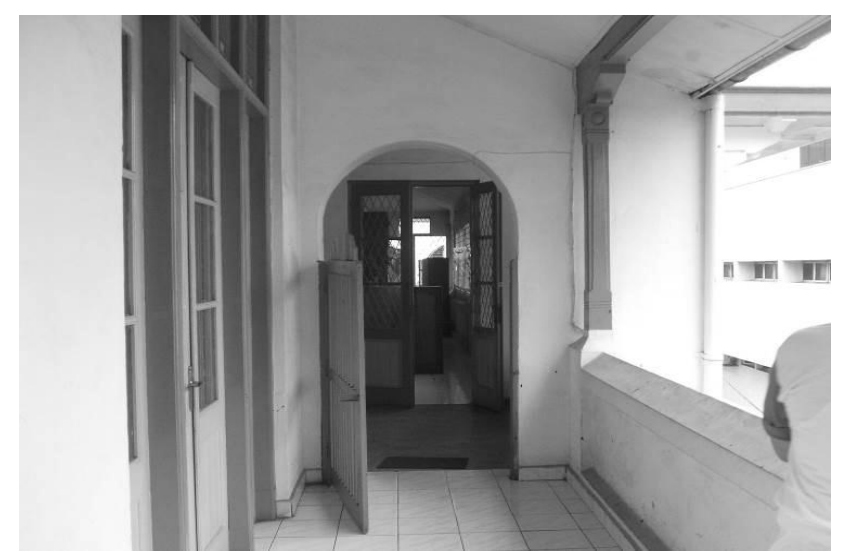

Sumber : survey lapangan, 2017

Gambar 9. Bagian Selasar Menuju Ruang Administrasi 
Ketersediaan fasilitas ruang terbuka kawasan pada zona perkantoran dan jasa di sekeliling lapangan Merdeka merupakan memberikan jaminan keberlanjutan ruang kota (Yurnita, Trisutomo, \& Ali, 2017) dan desain yang ekologis (Gunawan, 2018). Dengan mengambil sampel bangunan kantor pos Medan dan lapangan Merdeka sebagai ruang terbuka ditemukan hubungan langsung antara ruang terbuka hijau dengan bangunan kantor pos berupa konsep arsitektur hibrida dan merupakan aspek keberlanjutan desain yang mengadopsi konsep lokal. Secara politis merupakan pengakuan atau adaptasi kolonial atas unsur-unsur lokal yang diterima karena memperkuat hegemoni kolonial.

Pengaruh faktor fisik akan mempengaruhi kualitas visual ruang terbuka (Sudradjat, Martokusumo, \& Faisal, 2017). Keberadaan bangunan kantor pos dengan ciri arsitektur hibrida memperkuat kesan visual urban desain lapangan Merdeka. Demikian pula penelitian ini membuka peluang lebih jauh untuk mengungkap pengaruh fisik semua bangunan yang melingkupi lapangan Merdeka.

Desain bangunan kantor pos dan urban desain lapangan Merdeka merupakan karya pemerintah Belanda yang memadukan konsep lokal dan modern sebagai pengaruh globalisasi. Pada era ini, beberapa karya pemerintah kolonial Belanda telah menggabungkan pengaruh global dan lokal terutama pada desain rumah tinggal (Nas, 1998). Pemerintah Belanda kala itu bertindak sebagai stakeholder atau pemangku kebijakan dalam perencanaan tata ruang kota Medan. Tingkat pemahaman stakeholder dapat berpengaruh terhadap kualitas perencanaan bangunan dan kota. Peran pemahaman stakeholder ini sangat berguna bagi proses verifikasi, pemberian masukan, pertimbangan, dan perbaikan terhadap kajian dokumen perencanaan (Rahmawati, 2017).

\section{KESIMPULAN}

Konsep arsitektur Kantor Pos dan konsep Lapangan Merdeka merupakan satu kesatuan konsep karya pemerintah Belanda di Medan kala itu yang 'mengawinkan' konsep kolonial dan konsep lokal. Konsep bangunan kantor pos, yang menjadi penanda titik nol kota, berada di lapangan Merdeka yang didesain sebagai pusat kota yang menyerupai pusat kota tradisional/ alun-alun di Jawa. Konsep keberlanjutan dan konsep ekologis telah diterapkan oleh pemerintah Belanda sebagai stakeholder kala itu

Keberadaan dan Arsitektur Kantor pos Medan yang menandai titik nol kota Medan memberikan kualitas visual secara fisik yang keberadaanya memperkuat desain lapangan Merdeka. Alkulturasi budaya lokal Batak, Melayu, budaya Islam serta Belanda sebagai pendatang memberikan konsep penataan kota Medan terutama pada pusat pemerintahan di lapangan Merdeka memiliki ciri hybrid urban design. Lapangan Merdeka dan keberadan kantor pemerintahan bisa dikatakan tiruan dari konsep alun-alun. Alun-alun merupakan halaman depan pusat pemerintahan. Sementara itu, keberadaan kantor-kantor yang dirancang oleh Belanda di kawasan lapangan Merdeka mencirikan adanya kota dengan perekonomian yang maju yang memfasilitasi ekspor tembakau.

Keberadaan kantor pos memiliki ciri arsitektur hibrida (Melayu, Belanda, Islam) memperjelas bentuk dan konsep lapangan Merdeka yang memiliki filosofi tempat pertemuan berbagai budaya yang juga memiliki konsep hibrida, perkawinan antara konsep pusat kota tradisional di Jawa dan pusat kota di Belanda.

Dapat disimpulkan bahwa perancangan kota Medan dan kantor pos sebagai salah satu sampel bangunan karya arsitek Belanda yang berada di lapangan Merdeka menerapkan unsur-unsur konsep turunan/ peranakan/ hibrida konsep Jawa, Melayu, Arab dan Belanda. Pada konteks arsitektur, pemikiran konseptual karya kolonial ini telah menggabungkan globalisasi dan lokalitas pada desainnya. Kehilangan akibat kerusakan 
atau pembangunan yang disengaja pada elemen-elemen utama arsitektur yang menjadi unsur hibrida dapat mengakibatkan penurunan ciri khas bangunan dan lingkungan.

Penelitian ini masih dibatasi pada eksplorasi elemen fisik arsitektur pada bangunan cagar budaya Kantor Pos Medan. Temuan tentang elemen-elemen arsitektur tersebut seperti ciri-ciri, serta karakter hibrida sebagai ciri khas gaya Indies memiliki kegunaan signifikan pada pengkayaan sejarah arsitektur Indonesia. Manfaat strategis lain adalah memberikan panduan dalam pelaksanaan konservasi bangunan sehingga tidak menghilangkan karakter dan jati diri bangunan. Perlu disampaikan bahwa dalam kerangka pendalaman sejarah dan budaya "Indies Arsitektur" tidak tertutup kemungkinan dilanjutkan pada penelitian mengenai obyek-obyek arsitektur lain di Medan sebagai komparasi. Adapun dalam konteks pendayagunaan bangunan cagar budaya sebagai aset maka penelitian mengenai revitalisasi yang tetap mempertahankan karakter dan mendukung konsep upaya bangunan membiayai dirinya sendiri.

\section{UCAPAN TERIMA KASIH}

Penulis ingin ungkapkan rasa syukur dan terima kasih kepada PT. Kantor Pos Indonesia yang telah berkenan memberikan ijin survei dan pinjaman data-data bangunan kantor pos. Kerjasama penelitian lebih lanjut merupakan kesempatan bagi penulis untuk melakukan pendataan bangunan kantor pos di Jawa sebagai bangunan cagar budaya.

\section{DAFTAR PUSTAKA}

Ali, M. C. (2014). Exploring the potential of integration quality assessment system in construction (qlassic) with ISO 9001 quality management system (QMS). International Journal for Quality Research, 8(1), 73-86. https://doi.org/10.1088/1755-1315/

Coté, J. (2014). Thomas karsten's indonesia: Modernity and the end of europe, 1914-1945. Bijdragen Tot de Taal-, Land- En Volkenkunde, 170(1), 66-98. https://doi.org/10.1163/22134379-17001004

Geldern, H. R. (1982). Konsepsi Tentang Negara dan Kedudukan Raja di Asia Tenggara. Jakarta: CV. Rajawali.

Ginting, N., \& Rahman, N. V. (2016). Maimoon Palace Heritage District in Medan, Indonesia: What We Preserve and Why We Preserve? Procedia - Social and Behavioral Sciences, 222, 332-341. https://doi.org/10.1016/j.sbspro.2016.05.177

Gunawan, A. (2018). Konsep Desain Ekologis Ruang Terbuka Hijau di Sudirman Central Business District ( Scbd ) sebagai Habitat Burung. Tata Loka, 20(2), 181-194.

Handinoto. (1992). Alun-alun sebagai identitas kota jawa, dulu dan sekarang ., (September), 1-15.

Hartono., \& H. (2007). Arsitektur Transisi Di Nusantara Dari Akhir Abad 19 Ke Awal Abad 20. Surabaya: Fakultas Teknik Sipil dan Perencanaan, Jurusan Arsitektur.

Hartono, S. (1972). Jogjakarta and Cakranegara ., 1-11.

Hartono, S. (2005). Alun-Alun dan Revitalisasi Identitas Kota Tuban. Dimensi Teknik Arsitektur, 33 (No1), 1311.

Hidayat, M. S. (2017). Perencanaan Lingkungan dan Bangunan Berkelanjutan di Indonesia: Tinjauan Dari Aspek Peraturan Perundang-Undangan. Tata Loka, 19(1), 15-28. https://doi.org/10.14710/tataloka.19.1.15-28

Julaihi Wahid, Bambang Karsono, B. A. (2009). Morfologi Kota Medan Awal Terbentuk hingga Masa Kolonial (pp. 510-519). Semarang: Badan Penerbit Universitas Diponegoro.

Karsono, B. (2008). Imaginary axis as a basic morphology in the city of yogyakarta - indonesia.

Mandai, A. J. . (2016). Kajian Perilaku Berjalan Kaki Pada Kawasan Lapangan Merdeka di Kota Medan. Universitas Sumatera Utara.

Mulyadi, L. (2010). Review on Main Characteristic of Historical City as an Urban Design Alternative : A case study in Cakranegara City , Indonesia, 3666(2004), 1-15.

N Sudarmadji, B Tyaghita, P T Astuti, D. E. (2018). Medan City : Informality and the Historical Global City Medan City: Informality and the Historical Global City. 
Nas, P. J. M. (1998). The house in Indonesia; Between globalization and localization. Bijdragen Tot de Taal-, Land- En Volkenkunde / Journal of the Humanities and Social Sciences of Southeast Asia, 154(2), 335360. https://doi.org/10.1163/22134379-90003901

Pasaribu, D. S. ; J. D. (n.d.). Karakteristik Struktur Kota dan Pengaruhnya Terhadap Pola Pergerakan Di Kota Medan, (1), 1-11.

Pole, C. J. (2004). Seeing Is Believing ? Approaches To Edited By. Studies in Qualitative Methodology Volume 7 (Vol. 7).

Pratiwo.P.Nas. (2002). Java and De Groote Postweg, La Grande Route , the Great Mail Road, Jalan Raya Pos, $158,707-725$.

Pratiwo. (2004). The City Planning of Semarang 1900-1970 . (pp. 1-18). Surabaya.

Rahmawati, P. (2017). Penyusunan Rencana Zonasi Wilayah Pesisir di Kabupaten Jepara ( Studi Kasus : Desa Bandengan Kecamatan Jepara ). Tata Loka, 19(3), 192-205.

Rukayah, Siti, R and Hartuti, S. (2013). Islamic City Structure in Sekayu Semarang (The Viewpoint of Urban Design).

Siregar, M. I. (2015). Perubahan dan Keberlanjutan Pola Ruang Pada. Program Studi Teknik Arsitektur Fakultas Teknik USU Medan dengan.

Siti, R., Dhanang, R., \& and Endang, S. (2016). Morphology of Traditional City Center in Semarang: Towards Adaptive re- use in urban heritage. Environment-Behaviour Proceedings Journal, 1(4), 109-118. Retrieved from https://ebpj.e-iph.co.uk/index.php/EBProceedings/article/view/91/pdf

Sudradjat, I., Martokusumo, W., \& Faisal, B. (2017). Development of Visual Quality Evaluative, 256-265.

Sumalyo, Y. (1993). Arsitektur Kolonial Belanda di Indonesia. Yogyakarta: Gadjah Mada University Press.

Yahaya, I. F. and. (2017). Identification and Documentation of the Immovable Cultural Heritage in Medan City, North Sumatra.

Yurnita, A., Trisutomo, S., \& Ali, M. (2017). Model Reklamasi Pantai secara Berkelanjutan Kasus : Pantai Kota Makassar, 339-354. 